\title{
Effect of Asparaginase Enzyme in the Reduction of Asparagine in Green Coffee
}

\author{
Ana Carolina Vieira Porto ${ }^{1,2}$, Otniel Freitas-Silva ${ }^{1,2, * \mathbb{C}}$, Erika Fraga de Souza ${ }^{1,2}$ and \\ Leda Maria Fortes Gottschalk ${ }^{2}$ \\ 1 Food and Nutrition Postgraduate Program, Department of Food Technology, Nutrition School, \\ Federal University of Rio de Janeiro State-UNIRIO, Av. Pasteur, 296, Urca, 22290-240 Rio de Janeiro, Brazil; \\ ana_fobemo@hotmail.com (A.C.V.P.); erika.fraga@embrapa.br (E.F.d.S.) \\ 2 Embrapa Agroindústria de Alimentos, Av. das Américas, 29501, 23.020-470 Rio de Janeiro, Brazil; \\ leda.fortes@embrapa.br \\ * Correspondence: otniel.freitas@embrapa.br; Tel.: +55-21-3622-9645
}

Received: 10 January 2019; Accepted: 10 April 2019; Published: 1 May 2019

\begin{abstract}
Coffee is the most consumed beverage in the world, especially in Nordic countries. Its composition has substances considered to have high value for human health, such as chlorogenic and phenolic acids. However, the roasting of coffee can form substances such as acrylamide that are considered toxic and carcinogenic, depending on the time and the heat of roasting. However, there are some ways of reducing acrylamide formation during the processing of coffee beans. The reduction of its precursor asparagine is one of these ways. This can be achieved by the treatment of beans with the enzyme asparaginase. This study aimed to test the effectiveness of applying asparaginase (Acrylaway ${ }^{\mathrm{TM}}$ ) and evaluate the reduction of the amount of asparagine in Coffea arabica and C. canephora beans. The results showed the effectiveness of the enzyme in the reduction of free asparagine in green coffee beans of both species (C. arabica and C. canephora). Steam pretreatment was effective for the two species but required different times ( $30 \mathrm{~min}$ for C. arabica and $45 \mathrm{~min}$ for C. canephora). This can be attributed to the different chemical compositions found in the two species.
\end{abstract}

Keywords: asparaginase; Coffea arabica; Coffea canephora; acrylamide

\section{Introduction}

Coffee is the most consumed beverage in the world, especially in Nordic countries [1,2]. It contains substances considered to have high value for human health, such as chlorogenic and phenolic acids. However, these compounds are partially destroyed when the coffee beans are roasted [3]. The roasting of coffee also can form substances that are considered toxic and carcinogenic, such as acrylamide, depending on the time and heat of roasting [4,5]. Although lengthy roasting can reduce acrylamide formation by degrading this substance, other substances that are also carcinogenic can be formed [6]. Lengthy roasting causes degradation of the beneficial coffee components and changes sensory characteristics of the beverage [7].

Acrylamide has been classified by the International Agency for Research on Cancer as a potentially carcinogenic substance formed when carbohydrate-rich foods are fried, baked or toasted above $120^{\circ} \mathrm{C}$ (dry heat) in Maillard's reaction. However, chemical routes are not completely elucidated. Evidence points to asparagine as the main amino acid involved in the Maillard reaction as one of the key precursors in the mechanism of acrylamide formation [7].

Since 2002, the food industry worldwide has collaborated with scientists, in order to reduce the levels of acrylamide in cooked foods. Mitigation techniques can be separated into three different types. Firstly, starting materials low in acrylamide precursors can be used to reduce the acrylamide in the final 
product. Secondly, process conditions may be modified, in order to decrease the amount of acrylamide formation. Thirdly, post-process intervention could be used to reduce acrylamide [8].

There are other ways of reducing acrylamide formation [9] during the processing of coffee beans. The reduction of asparagine is one of these ways and can be achieved from the use of the enzyme asparaginase [10-13]. The available commercial enzymes have been tested in chips [14], with promising results showing $90 \%$ reduction of acrylamide formation in the final product and no changes in the sensory characteristics [15].

Numerous papers have demonstrated that acrylamide formation is proportional to reducing sugar concentrations in a potato $[16,17]$, while in cereals, such as rye and wheat, acrylamide formation is proportional to asparagine content $[18,19]$. It is clear, however, that little or no acrylamide will form in the absence of asparagine, while other components of the food matrix, such as lipid-derived aldehydes [20], amino acids such as serine and threonine [21], and other carbonyl-containing molecules [22,23], can react with asparagine to form acrylamide also.

Asparagine is the main precursor of acrylamide during the roasting of coffee beans, so its reduction means a lower concentration of acrylamide after beans are roasted [24,25].

Roast and ground coffee are not consumed as such but prepared as a beverage. Coffee is prepared by the addition of hot water and subsequent filtration [6]. Thus, calculation of the acrylamide content per cup is an important term of exposure level. Coffee has, in some cases, been reported to contribute substantially to the total dietary intake of acrylamide, especially in Nordic countries. In Sweden, an early study showed that the mean intake from coffee was estimated at $12 \mu \mathrm{g}$ day, which is roughly $39 \%$ of the total dietary intake [26].

The study aimed to test the effectiveness of the asparaginase enzyme treatment in green beans and evaluate the reduction of the amount of asparagine in the two main species of coffee, C. arabica and C. canephora.

\section{Materials and Methods}

\subsection{Coffee Samples}

The coffee beans used for analysis were Coffea arabica and C. canephora. All samples were acquired from producing regions in the states of Minas Gerais (C. arabica) and Espiríto Santo (C. canephora) in Brazil, and both green coffee samples were from 2015 season.

\subsection{Pretreatment with Steam}

To evaluate the influence of enzymatic treatment, a step for opening the pores of the bean to the enzymatic treatment was used. Approximately $10 \mathrm{~g}$ of green coffee beans selected (per assay) was separated and subjected to direct contact with flowing steam $\left(100^{\circ} \mathrm{C}\right.$ ) for 0 (control) $\mathrm{min}, 15 \mathrm{~min}$, $30 \mathrm{~min}, 45 \mathrm{~min}, 60 \mathrm{~min}$.

\subsection{Enzymatic Treatment}

Some parameters were provided by the company concerning the reaction conditions of the enzyme Acrylaway ${ }^{\mathrm{TM}}$ as ideal temperature, $\mathrm{pH}$, among others (data not published). Table 1 shows the HPLC parameters used for extraction, amino acid profile and asparagine analysis, following methodology previously used at Embrapa Food technology Labs.

Coffee beans with pores opened by steam treatment were hydrolyzed with an asparaginase solution (Acrylaway ${ }^{\mathrm{TM}}$ ). Samples weighing $10 \mathrm{~g}$, subjected or not to the steam pretreatment, were transferred to $250-\mathrm{mL}$ Erlenmeyer flasks, to which $1.47 \mathrm{~mL}$ of asparaginase enzyme was added, diluted 100 times with deionized water, after which the volume was completed with deionized water, to assure the $\mathrm{pH}$ that was considered optimal for the enzyme.

In this condition, the enzymatic load was 3500 ASNU (units of enzyme measurement)/g of dry coffee and the amount of water was $60 \%$ (so that all the water was absorbed after $1 \mathrm{~h}$ of hydrolysis). 
The coffee beans were placed in an oven at $80{ }^{\circ} \mathrm{C}$ for approximately $2 \mathrm{~h}$, until complete drying. The enzymatic loads chosen for test were: 3000 ASNU, 6000 ASNU, 9000 ASNU, 12,000 ASNU and $15,000 \mathrm{ASNU}$. For grinding, the granulometry was fixed as fine $(0.5 \mathrm{~mm})$.

Table 1. Parameters for enzyme reactions conditions.

\begin{tabular}{cc}
\hline Parameter & Reaction Conditions \\
\hline Temperature & $37.0 \pm 0.5^{\circ} \mathrm{C}$ \\
$\mathrm{pH}$ & $7.00 \pm 0.05$ (at room temperature) \\
L-asparagine & $9.2 \mathrm{mg} / \mathrm{mL}$ \\
Enzyme working range & $0.0207-0.0775 \mathrm{ASNU} / \mathrm{mL}$ \\
Interval kinetic measuring time & $2 \mathrm{~min}$ Incubate $1.5 \mathrm{~min}$ before measuring \\
\hline Wavelength & $340 \mathrm{~nm}$ \\
NADH & $0.405 \mathrm{mg} / \mathrm{mL}$ \\
\hline
\end{tabular}

\subsection{Asparagine Extraction}

One-gram ground coffee samples were placed in $25 \mathrm{~mL}$ flasks, to which $0.1 \mathrm{M}$ of $\mathrm{HCl}$ was added. The flasks were placed in an ultrasound bath for $20 \mathrm{~min}$, after which the solution was transferred to $50 \mathrm{~mL}$ Falcon tube and centrifuged for $10 \mathrm{~min}$ at $4500 \mathrm{rpm}$. After centrifugation, the solution was transferred to test tubes, which were vortexed. Then the samples were micro-filtered (mesh of $0.22 \mu \mathrm{m}$ ), vortexed again and transferred to $1 \mathrm{~mL}$ Eppendorf tubes.

\subsection{Derivatization of Amino Acids}

Two $\mathrm{mg}$ of aspartic acid was placed in a flask and completed to $50 \mathrm{~mL}$ with $0.1 \mathrm{M}$ of $\mathrm{HCl}$. The oven was preheated to $55^{\circ} \mathrm{C}$. Then $10 \mu \mathrm{L}$ of the calibration standard was removed and placed in a vial, into which $70 \mathrm{uL}$ of borate buffer (AccQ-Fluor Borate Buffer) was pipetted, followed by vigorous vortexing for $5 \mathrm{~s}$. Then $20 \mathrm{uL}$ of AQC (AccQ-Fluor Reagent Powder) was transferred into the same vial, which was vortexed for $10 \mathrm{~s}$ and then left at rest for $1 \mathrm{~min}$ to terminate the reaction. The whole reaction volume was transferred to a volume reducer and placed in an oven at $55 \pm 1{ }^{\circ} \mathrm{C}$ for $10 \mathrm{~min}$. Each $5 \mu \mathrm{L}$ of the injected volume contained 50 pmol of each derived amino acid (except cystine, which is equivalent to $25 \mathrm{pmol})$.

\subsection{Chromatographic Analysis}

The gradient used in the methods was as defined in the Empower ${ }^{\mathrm{TM}}$ software. An AccQ.Tag ${ }^{\circledR}$ chromatographic column measuring $3.9 \mathrm{~mm} \times 150 \mathrm{~mm}$ (Waters, Milford, MA, USA) was used, or alternatively, a Hypersil BDS C18 column (Thermo Scientific, Waltham, MA, USA) measuring $100 \mathrm{~mm}$ $\times 4.6 \mathrm{~mm}$, with a sample particle size of $2.4 \mu \mathrm{m}$.

The chromatographic conditions were: AccQ Tag ${ }^{\circledR}$ column, measuring $3.9 \mathrm{~mm} \times 150 \mathrm{~mm}$ (Waters, USA); BDS Hypersil C18 alternative column, measuring $100 \mathrm{~mm} \times 4.6 \mathrm{~mm}$; pre-column with the same phase as the column (optional); column temperature of $37^{\circ} \mathrm{C}$; injector temperature of $15^{\circ} \mathrm{C}$; elution gradient of mobile phase A, consisting of AccQ Tag ${ }^{\circledR}$ solution (Waters, USA) diluted 1:10 in Milli-Q water; mobile phase $B$ of acetonitrile; mobile phase $C$ of fresh Milli-Q water; flow of $1.0 \mathrm{~mL} / \mathrm{min}$; fluorescence detector: lexc $=250 \mathrm{~nm}$ and lem $=395 \mathrm{~nm}$; standard injection volume of $5 \mathrm{~mL}$; run time of $45 \mathrm{~min}$; delay time of $10 \mathrm{~min}$.

\section{Results and Discussion}

\subsection{Influence of Stream Pretreatment}

As can be observed in Figure 1, the best pretreatment for the $C$. arabica beans was 30 min, causing a reduction of approximately $60 \%$ in the amount of asparagine compared with the sample without 
pretreatment. Figure 2 also shows that the best pretreatment time for C. canephora was 45 min, causing a reduction of approximately $35 \%$ in the amount of asparagine.

\section{C. arabica ( $\mathrm{mg}$ asparagine/ $\mathrm{kg}$ coffee)}

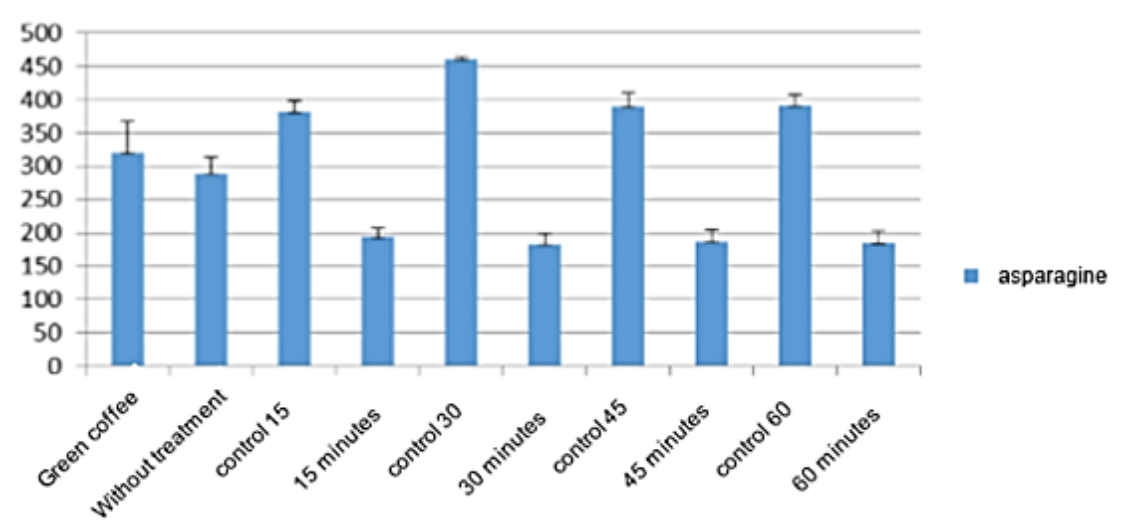

Figure 1. Influence of pretreatment with steam in C. arabica.

\section{C. canephora (mg asparagine/ $\mathrm{kg}$ coffee)}

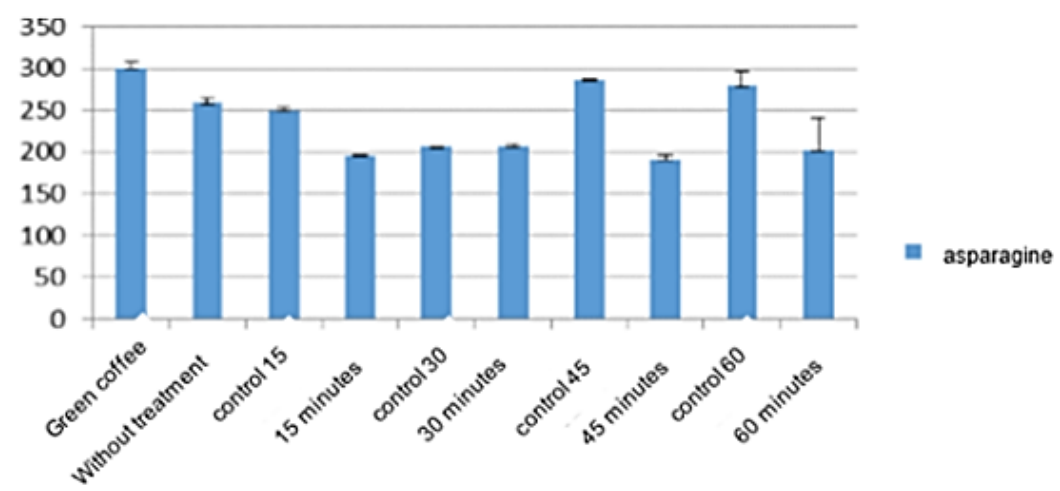

Figure 2. Influence of pretreatment with steam in C. canephora.

For coffee, increased acrylamide mitigation could be achieved by incubating the wetted green beans. Typically, green coffee beans are steamed to decrease the caffeine content. The decaffeination process is usually carried out by a water or solvent partition system. Firstly, green coffee beans are steamed to make the caffeine available. Then, a solvent is used to extract the caffeine. Finally, the green beans are steamed again to remove any residual solvent [27].

The pretreatment with steam was implemented before the enzymatic treatment to ensure sufficient contact between enzyme and asparagine grains. Theoretically, the green coffee beans have to pass through the steam to allow the free asparagine to exit the pores. Green coffee beans have a very "tight" structure, with less than $7 \%$ pore volume, an average pore diameter of $10 \mathrm{~nm}$. The diameter of the enzymes is usually about $5-10 \mathrm{~nm}$, the same as large protein particles [28]. Thus, only a limited part of the beans can be reached by a relatively large amount of the enzyme. So, to change the internal structure of the original green coffee beans and better disseminate the asparagine, pretreatment with steam is required [29].

In a previous study of asparaginase application in coffee, Hendriksen [30] achieved good results (about $30 \%$ and $60 \%$ reduction in asparagine for C. canephora and C. arabica, respectively). 


\subsection{Analysis of Different Enzymatic Loads}

Experiments were carried out to find the best enzymatic load to be used in the two species studied (C. arabica and C. canephora) for subsequent analysis of the greatest reduction of asparagine. The enzymatic loads chosen were: 3000 ASNU, 6000 ASNU, 9000 ASNU, 12,000 ASNU and 15,000 ASNU. There was also a control group with no addition of the enzyme.

The best enzyme to reduce asparagine in both C. arabica and C. Canephora was 3000 ASNU (Figures 3 and 4). After this load, no significant further reduction was achieved.

\section{C. arabica (mg asparagine/ $\mathrm{kg}$ coffee)}

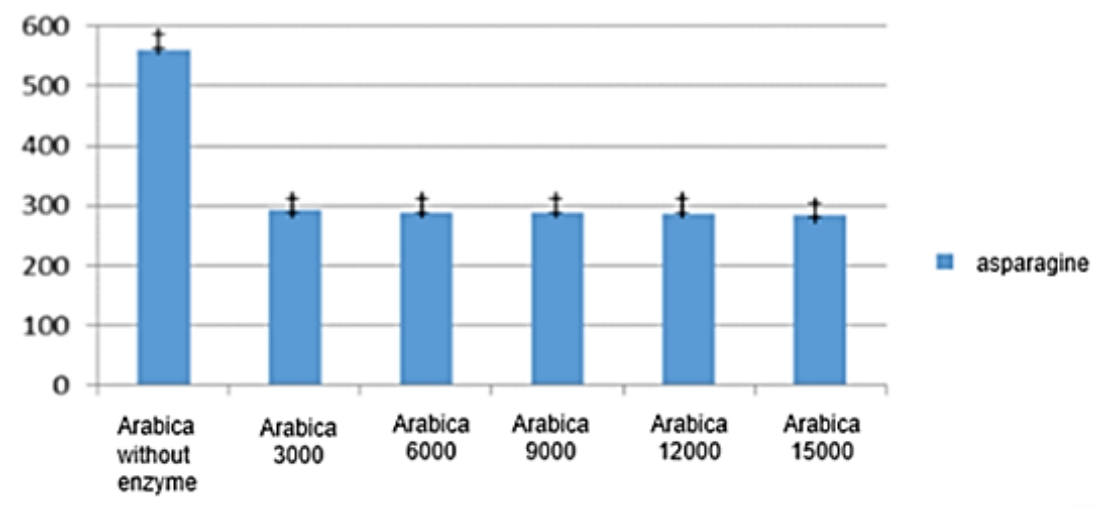

Figure 3. Asparagine reduction in C. Arabica depending on different enzyme concentrations.

\section{C. canephora (mg asparagine/ kg coffee)}

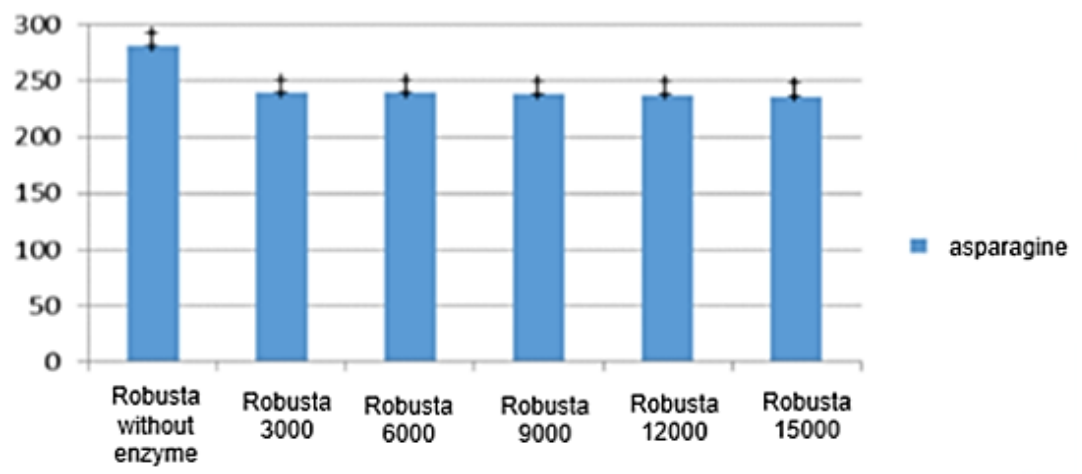

Figure 4. Asparagine reduction in C. canephora depending on different enzyme concentrations.

A study by the Association of Applied Biologists [31] also demonstrated varying levels of acrylamide and asparagine according to the use of different enzyme loads. The highest reduction was found for an enzyme load of 2000 ASNU and starting at a load of about 4000 ASNU, the reduction of both asparagine and acrylamide declined asymptotically.

The results showed that the enzyme load of 3000 ASNU reduced the asparagine level of the coffee by approximately $30 \%$. Also, there was a reduction of approximately the same percentage at the other loads enzymatic loads evaluated, but with stagnation. Therefore, to optimize the process and also to reduce the use of resources, we chose a load of 3000 ASNU as the most optimal amount for the enzymatic treatment of both coffee species.

A recent study showed that both the steaming step and the asparaginase treatment caused a reduction in free asparagine when the coffee was roasted, which was reflected in acrylamide losses from $69 \%$ to $86 \%$ using dosages of $2600-20,000$ ASNU, respectively [32]. However, there are no results demonstrating the sensory profile of the coffee beverage after the enzyme use [33]. Other treatments can 
be associated to the enzymatic ones, as dry processing or moist air velocity, to minimize the degradation of polyphenols and the antioxidant activity, and to reduce the relative formation of acrylamide in coffee beans [34] in attempting to find a balance for the quality and safety of the coffee beverage.

\section{Conclusions}

The results showed the effectiveness of the enzyme asparaginase (Acrylaway ${ }^{\mathrm{TM}}$ ) in reducing free asparagine in the green coffee beans, in both species (C. arabica and C. canephora). Asparaginase has become a powerful tool for acrylamide mitigation in the food industry. With the success of commercial products treated with this enzyme, it is likely that asparaginase will gain more applications in the food industry.

The steam pretreatment times tested showed effectiveness, however, with different optimal times (30 $\mathrm{min}$ for C. arabica coffee and $45 \mathrm{~min}$ for C. canephora). This can be attributed to the different botanical characteristics and chemical compositions of the two species. Because asparagine is considered the primary precursor in the formation of acrylamide during the Maillard reaction, its reduction by the use of enzyme treatment will also reduce the formation of acrylamide when these beans are roasted. However, studies should be conducted with roasted coffee to prove the potential of enzyme effectiveness in reducing the formation of acrylamide in coffee beans after they are roasted.

Although the amount of acrylamide has not been analyzed in this project, the most effective way to reduce acrylamide in heated foods is to reduce the precursor levels in raw food materials. Since asparagine has been described as the limiting factor for acrylamide formation in coffee, possible pre-processing mitigation strategies have been focused on asparagine reduction in green coffee beans.

The enzymatic degradation of asparagine present in raw materials previously to the heat processing by means of asparaginase have been shown to be one of the most promising mitigation strategies in a variety of foods, including coffee.

Due to the importance of reducing the formation of acrylamide in foods, it is viable to apply the enzyme asparaginase (acrylaway) in coffee beans, as it has been shown to be effective in reducing its main precursor in the formation of acrylamide (asparagine) and consequently, acrylamide. There are also applications in several other types of foods, as indicated by the guide for the food industry.

Author Contributions: The authors O.F.-S., L.M.F.G. have supervised this research work whereas the first author A.C.V.P. and E.F.d.S. have materially participated in this work. All authors also contributed in preparation of the manuscript, experimental and interpretation of data.

Funding: This study was financed in part by the Coordenação de Aperfeiçoamento de Pessoal de Nível Superior -Brasil (CAPES)-Finance Code 001for a scholarship from A.C.V.P., the National Research Council for Scientific and Technological Development (CNPQ-N. 477265/2012-0), the Brazilian Coffee Research and Development Consortium-CBP\&D), FAPERJ (Ref. Number E 26 202.749/2018).

Acknowledgments: The authors also wish to thank to Novozymes Latin American Ltda. for kindly donating the enzymes.

Conflicts of Interest: The authors declare that there is no conflict of interest.

\section{References}

1. Naidu, M.M.; Sulochanamma, G.; Sampathu, S.R.; Srinivas, P. Studies on extraction and antioxidant potential of green coffee. Food Chem. 2008, 107, 377-384. [CrossRef]

2. Dybing, E.; Farmer, P.B.; Andersen, M.; Fennell, T.R.; Lalljie, S.P.; Müller, D.J. Human exposure and internal dose assessments of acrylamide in food. Food Chem. Toxicol. 2005, 43, 365-410. [CrossRef]

3. Dias, E.D.; Borém, F.M.; Pereira, R.G.; Soares, C.; Cunha, S.; Fernandes, J.O. Determinação dos níveis de acrilamida em cafés verdes obtidos por diferentes processamentos. In Proceedings of the VI Simpósio de Pesquisa dos Cafés do Brasil, Vitória, ES, Brazil, June 2009.

4. Claeys, W.L.; De Vleeschouer, K.; Hendrickx, M.E. Quantifying the formation of carcinogens during food processing: Acrylamide. Trends Food Sci. Technol. 2005, 16, 181-193. [CrossRef] 
5. Friedman, M.; Levin, C.E. Review of methods for the reduction of dietary content and toxicity of acrylamide. Food Chem. 2008, 56, 6113-6140. [CrossRef] [PubMed]

6. Guenther, H.; Anklam, E.; Wenzl, T.; Stadler, R.H. Acrylamide in coffee: Review of progress in analysis, formation and level reduction. Food Addit. Contam. 2007, 24, 60-70. [CrossRef]

7. Lachenmeier, D.W.; Schwarz, S.; Teipel, J.; Hegmanns, M.; Kuballa, T.; Walch, S.G.; Breitling-Utzmann, C.M. Potential antagonistic effects of acrylamide mitigation during coffee roasting on furfuryl alcohol, furan and 5-hydroxymethylfurfural. Toxics 2018, 7, 1. [CrossRef]

8. IARC. Acrylamide. In IARC Monographs on the Evaluation of the Carcinogenic Risks to Humans: Some Industrial Chemicals; International Agency for Research on Cancer: Lyon, France, 1994; pp. 389-433.

9. Anese, M.; Suman, M.; Nicoli, M.C. Acrylamide removal from heated foods. Food Chem. 2010, 119, 791-794. [CrossRef]

10. Pedreschi, F.; Mariotti, M.S.; Granby, K. Current issues in dietary acrylamide: Formation, mitigation and risk assessment. J. Sci. Food Agric. 2014, 94, 9-20. [CrossRef]

11. Pedreschi, F.; Kaack, K.; Granby, K. The effect of asparaginase on acrylamide formation in French fries. Food Chem. 2008, 109, 386-392. [CrossRef]

12. Pedreschi, F.; Mariotti, S.; Granby, K.; Risum, J. Acrylamide reduction in potato chips by using commercial asparaginase in combination with conventional blanching. Food Sci. Technol. 2011, 44, 1473-1476. [CrossRef]

13. FDA (Food and Drug Administration). Guidance for Industry Acrylamide in Foods. Center for Food Safety and Applied Nutrition. Available online: https:/www.fda.gov/downloads/Food/GuidanceRegulation/ GuidanceDocumentsRegulatoryInformation/ChemicalContaminantsMetalsNaturalToxinsPesticides/ UCM374534.pdf (accessed on 20 November 2018).

14. FDE (Food Drink Europe). Acrylamide Toolbox Document. Available online: http://www.fooddrinkeurope. eu/uploads/publications_documents/Toolboxfinal260911.pdf (accessed on 20 August 2018).

15. Medeiros, V.R.; Mestdagh, F.; Van Poucke, C.; Kerkaert, B.; De Muer, N.; Denon, Q.; Van Peteghem, C.; De Meulenaer, B. Implementation of acrylamide mitigation strategies on industrial production of french fries: Challenges and pitfalls. J. Agric. Food Chem. 2011, 59, 898-906. [CrossRef]

16. Elmore, J.S.; Briddon, A.; Dodson, A.T.; Muttucumaru, N.; Halford, N.G.; Mottram, D.S. Acrylamide in potato crisps prepared from 20 UK-grown varieties: Effects of variety and tuber storage time. Food Chem. 2015, 182, 1-8. [CrossRef]

17. Vinci, R.M.; Mestdagh, F.; De Meulenaer, B. Acrylamide formation in fried potato products: Present and future, a critical review on mitigation strategies. Food Chem. 2012, 133, 1138-1154. [CrossRef]

18. Curtis, T.Y.; Powers, S.J.; Balagiannis, D.; Elmore, J.S.; Mottram, D.S.; Parry, M.A.; Halford, N.G. Free amino acids and sugars in rye grain: Implications for acrylamide formation. J. Agric. Food Chem. 2010, 58, 1959-1969. [CrossRef]

19. Halford, N.G.; Curtis, T.Y.; Muttucumaru, N.; Postles, J.; Elmore, J.S.; Mottram, D.S. The acrylamide problem: A plant and agronomic science issue. J. Exp. Bot. 2012, 63, 2841-2851. [CrossRef]

20. Zamora, R.; Hidalgo, F.J. Contribution of lipid oxidation products to acrylamide formation in model systems. J. Agric. Food Chem. 2008, 56, 6075-6080. [CrossRef]

21. Shu, C.K. Pyrazine formation from serine and threonine. J. Agric. Food Chem. 1999, 47, 4332-4335. [CrossRef]

22. Hamzalioglu, A.; Gökmen, V. Role of bioactive carbonyl compounds on the conversion of asparagine into acrylamide during heating. Eur. Food Res. Technol. 2012, 235, 1093-1099. [CrossRef]

23. Zamora, R.; Delgado, R.M.; Hidalgo, F.J. Strecker aldehydes and alpha-keto acids, produced by carbonylamine reactions, contribute to the formation of acrylamide. Food Chem. 2011, 128, 465-470. [CrossRef]

24. Mottram, D.S.; Wedzicha, B.L.; Dodson, A.T. Acrylamide is formed in the Maillard reaction. Nature 2002, 419, 448-449. [CrossRef]

25. Stadler, R.H.; Blank, I.; Varga, N.; Robert, F.; Hau, J.; Guy, P.A. Acrylamide from maillard reaction products. Nature 2002, 419, 449. [CrossRef]

26. Svensson, K.; Abramsson, L.; Becker, W.; Glynn, A.; Hellenäs, K.E.; Lind, Y.; Rose'n, J. Dietary intake of acrylamide in Sweden. Food Chem. Toxicol. 2003, 41, 1581-1586. [CrossRef]

27. Spiller, G.A. Caffeine; Taylor \& Francis: London, UK, 1997.

28. Schenker, S.; Handschin, S.; Frey, B.; Perren, R.; Eschere, E. Pore structure of coffee beansaffected by roasting conditions. J. Food Sci. 2000, 65, 452-457. [CrossRef]

29. Whitehurst, R.J.; Van Oort, M. Enzymes in food technology. Int. J. Food Sci. Technol. 2009, 53, $248-256$. 
30. Hendriksen, H.V.; Kornbrust, B.A.; Ostergaard, P.R.; Stringer, M.A. Evaluating the potential for enzymatic acrylamide mitigation in a range of food products using an asparaginase from aspergillus oryzae. J. Agric. Food Chem. 2013, 57, 4168-4176. [CrossRef]

31. Association of applied biologists. Acrylamide, furans and other food-borne contaminants: From. Plant Sci. Food Chem. 2013, 8-9.

32. Xu, F.; Khalid, P.; Oruna-Concha, M.; Elmore, S. Effect of asparaginase on flavour formation in roasted coffee. In Flavour Science, Proceedings of the XIV Weurman Flavour Research Symposium, Queen's College, Cambridge, UK, 15-19 September 2014; 2015; pp. 563-566.

33. Xu, F.; Oruna-Concha, M.J.; Elmore, J.S. The use of asparaginase to reduce acrylamide levels in cooked food. Food Chem. 2016, 210, 163-171. [CrossRef]

34. Budryn, G.; Nebesny, E.; Oracz, J. Correlation between the stability of chlorogenic acids, antioxidant activity and acrylamide content in coffee beans roasted in different conditions. Int. J. Food Prop. 2015, 2, $290-302$. [CrossRef] 